\title{
Subcellular Localization of Full-Length and Truncated Trk Receptor Isoforms in Polarized Neurons and Epithelial Cells
}

\author{
David Kryl, ${ }^{1}$ Talene Yacoubian, ${ }^{2}$ Annakaisa Haapasalo, ${ }^{3}$ Eero Castren, ${ }^{3}$ Donald Lo, ${ }^{2}$ and Philip A. Barker ${ }^{1}$ \\ ${ }^{1}$ Centre for Neuronal Survival, Montreal Neurological Institute, McGill University, Montreal, Quebec, Canada, H3A 2B4, \\ ${ }^{2}$ Department of Neurobiology, Duke University Medical Center, Durham, North Carolina 27710, and ${ }^{3}$ A. I. Virtanen \\ Institute, University of Kuopio, Kuopio, Finland
}

Neurotrophins affect neuronal development and plasticity via spatially localized effects, yet little is known about the subcellular distribution of the Trk neurotrophin receptors and the impact of this distribution on neurotrophin action. To address this, we examined the subcellular location of full-length TrkB and TrkC tyrosine kinase receptors and truncated TrkB isoforms after transfection of Madin-Darby canine kidney (MDCK) cells, dissociated primary hippocampal neurons, and cortical neurons within intact brain slices. Myc-, herpes virus glycoprotein (HVG)-, or FLAG-derived epitope-tagged receptor isoforms were created to allow their unambiguous identification and localization after transfection. All tagged receptors were appropriately synthesized, and full-length myc-TrkB and myc-TrkC mediated appropriate neurotrophin-signaling events. We found that full-length TrkB receptors were excluded from the apical domain of MDCK cells but that TrkC receptors were present in both apical and basolateral domains. Full-length TrkB and TrkC were found throughout transfected primary cultured hippocampal neurons and transfected neurons in neocortical brain slices and showed no evidence of vectorial sorting. Truncated forms of TrkB were also homogeneously distributed in MDCK cells, dissociated hippocampal neurons, and cortical neurons within slice preparations. Levels of full-length and truncated TrkB were examined in postsynaptic densities; both receptor isoforms were present but only moderately enriched in these structures. Together, these findings suggest that Trk receptors are uniformly distributed in both axonal and dendritic compartments and that local neurotrophin responses are controlled by other mechanisms.

Key words: neurotrophins; MDCK; vectorial sorting; hippocampal neurons; Trk; postsynaptic density
Neurotrophins play pleiotropic roles in nervous system development and plasticity (Davies, 1994; Snider, 1994; Thoenen, 1995; Lewin and Barde, 1996; McAllister et al., 1999). Some functions, such as the promotion of neuronal survival, exert global effects on neuronal cell state, whereas others, such as the regulation of synaptic plasticity, are more localized and produce subcellular changes in neural function. Neurotrophins may have effects that are localized to particular neuronal compartments, such as axons or dendrites, or even to specific dendritic branches or spines (Campenot, 1987; Stoop and Poo, 1996; Li et al., 1998; McAllister et al., 1999). In regulating neuronal morphology, neurotrophins exhibit differential effects on apical versus basal dendritic compartments of cortical pyramidal neurons (McAllister et al., 1995, 1997), suggesting that individual neurons are capable of domainspecific neurotrophin responses.

Neurotrophins mediate their effects by binding to two distinct classes of cell surface receptors. In mammals, the Trk family contains three highly homologous transmembrane receptor tyrosine kinases, whereas the $\mathrm{p} 75$ neurotrophin receptor is a member of the tumor necrosis factor receptor superfamily (for review,

Received Jan. 18, 1999; revised April 14, 1999; accepted April 27, 1999.

This work was supported by grants from the Canadian Neurosciences Network Program, the Medical Research Council (MRC) of Canada, the Fond de la Recherché en Santé du Quebec (P.A.B.), the McKnight Foundation, the National Institutes of Health (D.L.), and the Academy of Finland and by European Union Biotechnology Grant PL970259 to E.C. P.A.B. is an MRC Scholar and a Scholar of the Killam Foundation.

Correspondence should be addressed to Dr. Philip A. Barker, Centre for Neuronal Survival, 3801 University Avenue, Montreal, Quebec, Canada, H3A 2B4. Copyright @ 1999 Society for Neuroscience 0270-6474/99/195823-11\$05.00/0 see Naismith and Sprang, 1998). Ligand binding to Trk receptors activates several signaling cascades, including phosphatidylinositol-3-kinase, phospholipase C, SNT, and ras/mitogen-activated protein kinase pathways, that mediate growth and survival responses of the neurotrophins (for review, see Kaplan and Miller, 1997). The predominant types of Trk receptors expressed in the mammalian CNS are TrkB and TrkC. Both of these are produced primarily as full-length receptor tyrosine kinases early in development with alternatively spliced variants becoming more prevalent with increasing age (Valenzuela et al., 1993; Allendoerfer et al., 1994; Escandón et al., 1994; Knüsel et al., 1994; Fryer et al., 1996). TrkB-T1 and -T2 isoforms, which bind neurotrophin but lack most of the intracellular domain, are expressed at low levels in the prenatal rodent brain, but their expression levels increase postnatally, ultimately exceeding levels of full-length TrkB in adulthood (Valenzuela et al., 1993; Allendoerfer et al., 1994; Escandón et al., 1994; Knüsel et al., 1994; Fryer et al., 1996). Full-length and truncated TrkB isoforms are coexpressed within central neurons, whereas central glia produce only truncated TrkB isoforms (Rudge et al., 1994; Armanini et al., 1995; Wetmore and Olson, 1995). The physiological function of the TrkB-T1 and -T2 isoform receptors remains unclear, but they may serve as dominant-negative regulators of full-length TrkB receptors (Eide et al., 1996; Ninkina et al., 1996), may sequester ligand and limit diffusion (Biffo et al., 1995; Fryer et al., 1997), may recruit ligand and regulate cell morphology (Haapasalo et al., 1999), and may even autonomously activate signaling cascades in a neurotrophin-dependent manner (Baxter et al., 1997).

The mechanisms that restrict neurotrophin signaling to specific 
neuronal subdomains remain unknown, but one possibility is that Trk receptors are specifically concentrated within functionally distinct regions within the somatic, dendritic, and axonal compartments of neurons. Differential localization of multiple alternatively spliced Trk receptor variants could serve as a powerful mechanism for limiting neurotrophin responsiveness to particular subcellular domains and might explain why specific regions of single neurons show different responses to the same neurotrophin (McAllister et al., 1995, 1997; Li et al., 1998). To examine Trk receptor distribution, we created epitope-tagged forms of Trk receptors, determined their cellular distribution within epithelial cells and primary neurons, and performed biochemical analyses to establish whether full-length and truncated TrkB receptors were enriched in postsynaptic densities isolated from intact brain. Our results indicate that Trk receptor isoforms are uniformly distributed within neurons and that domain-specific receptor localization is unlikely to account for specific local effects of neurotrophins.

\section{MATERIALS AND METHODS}

Materials. The anti-myc antibody 9E10 was either produced in ascites fluid in Balb/c mice and purified using Immunopure columns (Pierce, Rockford, IL) according to the manufacturer's instructions or purchased from PharMingen (San Diego, CA). The pan-Trk antibody 203, the ZO-1 antibody, and the 5B6 antibody were kind gifts from David Kaplan (Montreal Neurological Institute), Bruce Stevenson (University of Alberta), and David Shelton (Genentech, San Francisco, CA), respectively. Antibodies directed against calcium calmodulin kinase-II (CaM kinaseII) were purchased from Upstate Biotechnology (Lake Placid, NY), GluRI and GluRII/III antibodies were purchased from Transduction Laboratories (Lexington, KY), polyclonal blue fluorescent protein (BFP) and green fluorescent protein (GFP) antibodies were purchased from Clontech (Cambridge, UK), MAP2 and tau antibodies were purchased from Sigma (St. Louis, MO), and M2 monoclonal antibody directed against the FLAG epitope was purchased from Eastman Kodak (Rochester, NY). Nerve growth factor (NGF) was purchased from Cedarlane (Hornby, Ontario, Canada), and brain-derived neurotrophic factor (BDNF) and neurotrophin-3 (NT-3) were provided by Regeneron Pharmaceuticals (Tarrytown, NY). Conjugated secondary antibodies were purchased from Jackson ImmunoResearch (West Grove, PA), Chemicon (Temecula, CA), Molecular Probes (Eugene, OR), or Sigma. pPML-cytomegalovirus (-CMV) expression plasmids containing truncated TrkB isoforms tagged with a 22 amino acid epitope tag derived from herpes virus glycoprotein (HVG) (Armanini et al., 1995) were obtained from David Shelton (Genentech).

Epitope tag insertion. cDNA fragments encoding the c-myc epitope were inserted into full-length TrkB and TrkC by PCR overlap, just distal to the putative signal peptide cleavage site (amino acid position 16 and 20 of processed TrkB and TrkC, respectively; see Fig. 1). PCR fragments obtained were sequenced to ensure fidelity and then cloned into the receptor open reading frame. These modified receptor cDNA constructs were expressed using either pCMX (Davis et al., 1991) or pRC-CMV (Invitrogen, San Diego, CA). Truncated TrkB-T1 was tagged with the eight amino acid FLAG epitope (Haapasalo et al., 1999) and expressed from the pEF-BOS expression plasmid (Mizushima and Nagata, 1990).

Tissue culture. Pheochromocytoma 12 (PC12) cells (Greene and Tischler, 1976) were maintained in DMEM containing 6\% horse serum (HyClone, Logan, UT) and 6\% newborn bovine calf serum (HyClone) in $7.5 \% \mathrm{CO}_{2}$ at $37^{\circ} \mathrm{C}$. Human embryonic kidney (HEK) 293 cells were maintained in DMEM containing 10\% newborn bovine calf serum in 5\% $\mathrm{CO}_{2}$ at $37^{\circ} \mathrm{C}$. Madin-Darby canine kidney (MDCK) cells were maintained in DMEM containing 10\% fetal bovine calf serum (Life Technologies, Gaithersburg, MD) in $5 \% \mathrm{CO}_{2}$ at $37^{\circ} \mathrm{C}$. Dissociated hippocampal cultures were established and maintained as described by Bartlett and Banker (1984) with slight modifications. Briefly, hippocampi from embryonic day 18 (E18) rat fetuses were trypsinized in PBS supplemented with $5 \%$ glucose and $10 \mathrm{~mm}$ HEPES, $\mathrm{pH} 7.4$, for $10 \mathrm{~min}$ and then triturated in $8 \mathrm{ml}$ of Neurobasal medium (Life Technologies) supplemented with $25 \mu \mathrm{M}$ glutamate and $500 \mu \mathrm{M}$ L-glutamine. After nondissociated clumps of neurons were allowed to settle, the top $2 \mathrm{ml}$ of the suspension was transferred to a second tube and replaced by $2 \mathrm{ml}$ of fresh medium in the first tube. This was repeated several times to collect sufficient numbers of neurons for plating. Cultures were supplemented with B27 (Life Technologies) and then plated on either coverslips or tissue culture plastic that had been precoated with poly-L-lysine and collagen. Medium was replaced $48 \mathrm{hr}$ after plating with Neurobasal containing B27 and $0.5 \mathrm{~mm}$ glutamine; cultures were subsequently maintained in this latter medium.

Visual cortical slices from 2-week-old ferrets were prepared and cultured with slight modifications of a previously described protocol (McAllister et al., 1995). Briefly, $400 \mu \mathrm{m}$ coronal slices of ferret cortex were prepared under sterile conditions in artificial CSF bubbled with $5 \%$ $\mathrm{CO}_{2} / 95 \% \mathrm{O}_{2}\left(124 \mathrm{~mm} \mathrm{NaCl}, 5 \mathrm{~mm} \mathrm{KCl}, 0.65 \mathrm{~mm} \mathrm{MgSO}_{4}, 3 \mathrm{~mm} \mathrm{CaCl}_{2}\right.$, $1.2 \mathrm{mM} \mathrm{KH}_{2} \mathrm{PO}_{4}, 10 \mathrm{~mm}$ dextrose, $26 \mathrm{~mm} \mathrm{NaHCO}_{3}$, and $1 \mathrm{~mm}$ kynurenic acid) and placed on culture inserts in six-well culture plates $(0.4 \mu \mathrm{m}$ pore size; Falcon). Culture medium (1.5 ml; $50 \% \beta$-mercaptoethanol, $25 \%$ HBSS, and 25\% horse serum; HyClone) containing $36 \mathrm{~mm}$ dextrose, 26 $\mathrm{mm} \mathrm{NaHCO}_{3}, 1 \mathrm{~mm}$ kynurenic acid, and $100 \mathrm{U} / \mathrm{ml}$ penicillin-streptomycin (Life Technologies; bubbled 10 min with $5 \% \mathrm{CO}_{2} / 95 \% \mathrm{O}_{2}$ ) was added under each insert, and the plates were incubated in $5 \% \mathrm{CO}_{2}$ at $37^{\circ} \mathrm{C}$ for $36-38 \mathrm{hr}$ before fixation for immunocytochemistry.

Transfections. Transfections of MDCK and PC12 cells were performed using Lipofectamine (Life Technologies) essentially according to the manufacturer's instructions. PC12 transfections were performed in the absence of serum for $4 \mathrm{hr}$ and then supplemented with PC12 medium for $20 \mathrm{hr}$ before initiating neurite extension assays (described below). For transient MDCK transfections, cells were plated on permeable membrane inserts (Falcon) before transfection. To produce stable MDCK sublines overexpressing Trk receptors, we transfected MDCK cells plated on tissue culture plastic and $2 \mathrm{~d}$ later split the cells into DMEM containing $10 \%$ fetal bovine calf serum and $400 \mathrm{mg} / \mathrm{ml} \mathrm{G} 418$ (Life Technologies). Medium was changed every $3 \mathrm{~d}$ for a period of $\sim 18 \mathrm{~d}$, after which G418-resistant colonies were further analyzed. Transfections of HEK293 cells and hippocampal neurons were performed using $\mathrm{CaPO}_{4}$ essentially as described (Ausebel et al., 1989; Xia et al., 1996).

Cortical slices were transfected by particle-mediated gene transfer using an entrainment biolistic device (Helios Gene Gun; Bio-Rad, Hercules, CA) according to the manufacturer's instructions. Gold particles $(1.6 \mu \mathrm{m})$ coated with plasmid DNA at $2 \mu \mathrm{g}$ of DNA per milligram of gold were adhered to Teflon tubing with $0.05 \mathrm{mg} / \mathrm{ml}$ polyvinylpyrrolidone and accelerated using $100 \mathrm{psi}$ helium. Transfections were done within 1-3 hr after slice preparation; after transfection, slices were maintained in a $37^{\circ} \mathrm{C}, 5 \% \mathrm{CO}_{2}$ incubator until they were fixed for immunocytochemistry.

Immunoprecipitation and immunoblotting. For immunoprecipitations, HEK293 cells were lysed in either radioimmunoprecipitation assay buffer (10 mm Tris, $150 \mathrm{~mm} \mathrm{NaCl}, 1 \% \mathrm{NP}-40,0.5 \%$ sodium deoxycholate, $0.1 \%$ SDS, $1 \mu \mathrm{g} / \mathrm{ml}$ leupeptin, $100 \mu \mathrm{M}$ phenylmethylsulfonyl fluoride, $5 \mathrm{~mm}$ phenanthroline, and $1 \mathrm{~mm}$ orthovanadate) or NP-40 buffer (20 mM Tris, $\mathrm{pH} 8.0,154 \mathrm{~mm} \mathrm{NaCl}, 10 \%$ glycerol, $1 \% \mathrm{NP}-40,1 \mu \mathrm{g} / \mathrm{ml}$ leupeptin, 100 $\mu \mathrm{M}$ phenylmethylsulfonyl fluoride, $5 \mathrm{~mm}$ phenanthroline, and $1 \mathrm{~mm}$ orthovanadate) for $20 \mathrm{~min}$. Lysates were scraped from plates, briefly vortexed, and spun in a microcentrifuge for $5 \mathrm{~min}$ at full speed to remove nuclei and other insoluble material. Lysates were normalized for protein content and then incubated overnight at $4^{\circ} \mathrm{C}$ with appropriate monoclonal or polyclonal antibodies. Anti-mouse IgG agarose (Sigma) or protein A-Sepharose beads (Pharmacia, Dorval, Quebec, Canada) were then added for $90 \mathrm{~min}$, precipitated, washed three times in lysis buffer, and resuspended in reducing Laemmli sample buffer. Samples were boiled 5 min, subjected to SDS-PAGE, and transferred to nitrocellulose under standard Towbin conditions. Membranes were rinsed once in TBS with Tween (TBST; $10 \mathrm{~mm}$ Tris, $150 \mathrm{~mm} \mathrm{NaCl}$, and $0.2 \%$ Tween-20) and blocked in Blotto $(10 \mathrm{~mm}$ Tris, $150 \mathrm{~mm} \mathrm{NaCl}$, and $5 \%$ nonfat dry skim milk) for $1 \mathrm{hr}$. Membranes were incubated with primary antibodies diluted in Blotto for $2 \mathrm{hr}$ at room temperature or overnight at $4^{\circ} \mathrm{C}$. After washing four times in TBST, blots were incubated $90 \mathrm{~min}$ in a solution of Blotto containing HRP-conjugated secondary antibodies diluted 1:10000. Blots were washed four times with TBST and then visualized using ECL (Amersham, Arlington Heights, IL).

Neurite extension assays. PC12 cells that do not extend neurites in response to BDNF or NT-3 were transiently transfected with pBA133 (vector control), pBA317 (encoding epitope-tagged full-length TrkB), or pBA292 (encoding epitope-tagged full-length TrkC) using Lipofectamine. Twenty-four hours after transfection, cells were washed twice with DMEM containing $0.1 \%$ bovine serum albumin (DMEB) and then incubated in DMEB containing no addition, containing BDNF (100 $\mathrm{ng} / \mathrm{ml})$, or containing NT-3 $(100 \mathrm{ng} / \mathrm{ml})$ for a period of $48 \mathrm{hr}$. Cells were 

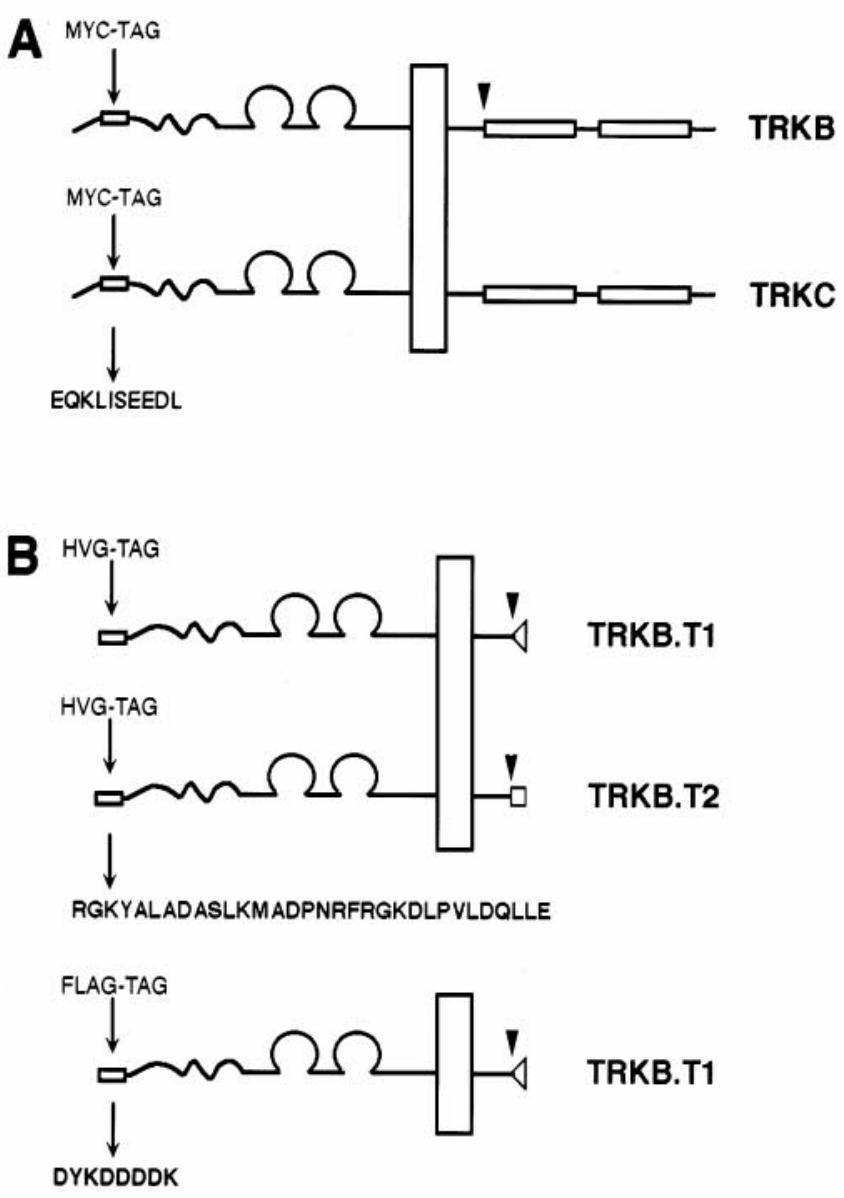

\section{C}

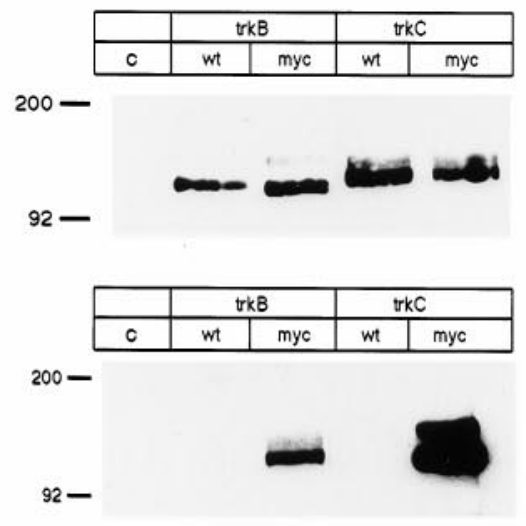

D

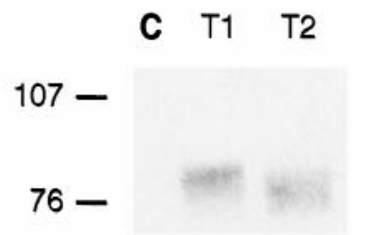

Figure 1. Epitope-tagged TrkB and TrkC receptors are fully processed and recognized by epitope tag-specific antibodies. $A, B$, Schematic representations of the placement of c-myc, HVG, and FLAG epitope tag insertion into full-length $\operatorname{TrkB}$ and $\operatorname{TrkC}(A)$ and truncated TrkB iso then fixed for immunocytochemistry as described below. Neurites extending greater than two cell body diameters were scored as positive.

Immunocytochemistry. PC12, HEK293, and MDCK cells were prepared for immunocytochemistry $72 \mathrm{hr}$ after transfection. PC12 and MG87 cells were fixed in PBS containing 4\% formaldehyde and $0.12 \mathrm{M}$ sucrose for $20 \mathrm{~min}$ at room temperature. Hippocampal neurons were fixed in PBS containing $4 \%$ formaldehyde, $0.12 \mathrm{M}$ sucrose, and $0.3 \%$ Triton X-100 or in 50\% methanol and 50\% acetone. For MDCK cells grown on filter supports, a 5 min fixation in 50\% methanol and 50\% acetone at room temperature best preserved the $\mathrm{Z}$ axis for confocal microscopy and was used for all MDCK immunocytochemistry. Subsequent immunocytochemical steps were the same for all cells. Control experiments (data not shown) confirmed that intracellular epitopes are not detected immunocytochemically after fixation with $4 \%$ paraformaldehyde if cells were not permeabilized with $0.3 \%$ Triton X-100. After fixation, cells were washed once in PBS and then blocked with PBS containing $2 \%$ goat serum for $1 \mathrm{hr}$ at $37^{\circ} \mathrm{C}$. Primary antibodies diluted in PBS containing $2 \%$ goat serum were applied for $1 \mathrm{hr}$ at room temperature, and then cells were washed twice in PBS. 5B6 and 9E10 were used at $1 \mu \mathrm{g} / \mathrm{ml}$, and M2 was used at $2.5 \mu \mathrm{g} / \mathrm{ml}$. ZO-1 was used at a dilution of 1:250. Fluorochrome-conjugated secondary antibodies were applied for $1 \mathrm{hr}$ at room temperature at a dilution of 1:800. Cells were washed twice in PBS, coverslipped, and photographed either on an inverted Zeiss ICM405 fluorescence microscope or on a Zeiss LSM410 confocal microscope.

For immunohistochemistry of transfected neurons in brain slices, transfected slices were fixed in $2.5 \%$ paraformaldehyde and $4 \%$ sucrose in PBS, saturated in $30 \%$ sucrose, and freeze-thawed to enable penetration of antibodies. After a $3 \mathrm{hr}$ incubation in blocking solution (10\% goat serum, $2 \%$ bovine serum albumin, and $0.25 \%$ Triton X-100 in $0.1 \mathrm{M}$ phosphate buffer), slices were incubated overnight with primary antibody at $4^{\circ} \mathrm{C}$. M2 monoclonal antibody was used at 1:1000 dilution for TrkB-T1and -T2-transfected cells. 9E10 was used at 1:250-1:500 dilution for myc-TrkB- and myc-TrkC-transfected cells. Anti-GFP antibody was used at 1:2000 dilution for GFP-transfected cells. After several washes in blocking solution, slices transfected with truncated or full-length Trk receptors were incubated for $4 \mathrm{hr}$ at room temperature with Cy3-, FITC-, or Oregon green 488-conjugated secondary antibodies. A Zeiss Axiophot microscope was used for epifluorescence microscopy using standard filters for rhodamine and fluorescein.

Subcellular fractionation. The postsynaptic density (PSD) fractions were prepared as described by Carlin et al. (1980) with slight modifications. All steps were done at $4^{\circ} \mathrm{C}$. Adult Wistar rat brains were homogenized in $0.32 \mathrm{~m}$ sucrose supplemented with $1 \mathrm{~mm} \mathrm{NaHCO}, 10 \mathrm{~mm}$ benzamidine, $10 \mathrm{~mm}$ leupeptin, and $50 \mathrm{~mm}$ PMSF to produce crude homogenate. This was centrifuged for $10 \mathrm{~min}$ at $1400 \times g$, and the resulting supernatant was then centrifuged at $710 \times g$ for $10 \mathrm{~min}$. The supernatant was centrifuged at $13800 \times g$ for $10 \mathrm{~min}$ to give pellet $\mathrm{P} 2$. Pellet P2 was resuspended in $7.5 \mathrm{ml} /$ brain of $0.32 \mathrm{M}$ sucrose with $1 \mathrm{~mm}$ $\mathrm{NaHCO}_{3}$, and $4 \mathrm{ml}$ of this solution was layered onto a sucrose density gradient consisting of $3 \mathrm{ml}$ each of $0.85,1.0$, and $1.2 \mathrm{M}$ sucrose in $1 \mathrm{~mm}$ $\mathrm{NaHCO}_{3}$. The gradient was centrifuged at $82500 \times g$ for $2 \mathrm{hr}$, and a glass pipet was used to remove the postsucrose membrane fraction between 1.0 and $1.2 \mathrm{M}$ sucrose. This fraction was diluted with Triton X-100 to a final concentration of $0.5 \%$ and spun $20 \mathrm{~min}$ at $32800 \times g$ to produce the PSD fraction. One-half of the pellets were resuspended in $1.8 \mathrm{ml}$ of $0.5 \%$ Triton X-100 and spun at $50000 \times g$ for $1 \mathrm{hr}$ to give the double-extracted PSD fraction. Final fractions were resuspended in Laemmli buffer.

$\leftarrow$

forms $(B)$ are shown. Arrowheads show the point of sequence divergence between full-length and truncated TrkB isoforms. $C$, HEK293 cells were transiently transfected with myc-TrkB and myc-TrkC, and the receptors were immunoprecipitated with pan-Trk antibody 203 and immunoblotted with antibody 203 (top) or with 9E10 (bottom). D, HEK293 cells transiently transfected with tagged TrkB-T1 or -T2 were immunoprecipitated with 5B6 and immunoblotted with 5B6. Lane $C$ (lane $c$ in $C$ ) represents immunoprecipitate from control, nontransfected HEK293 cells. $w t$, Wild type. 

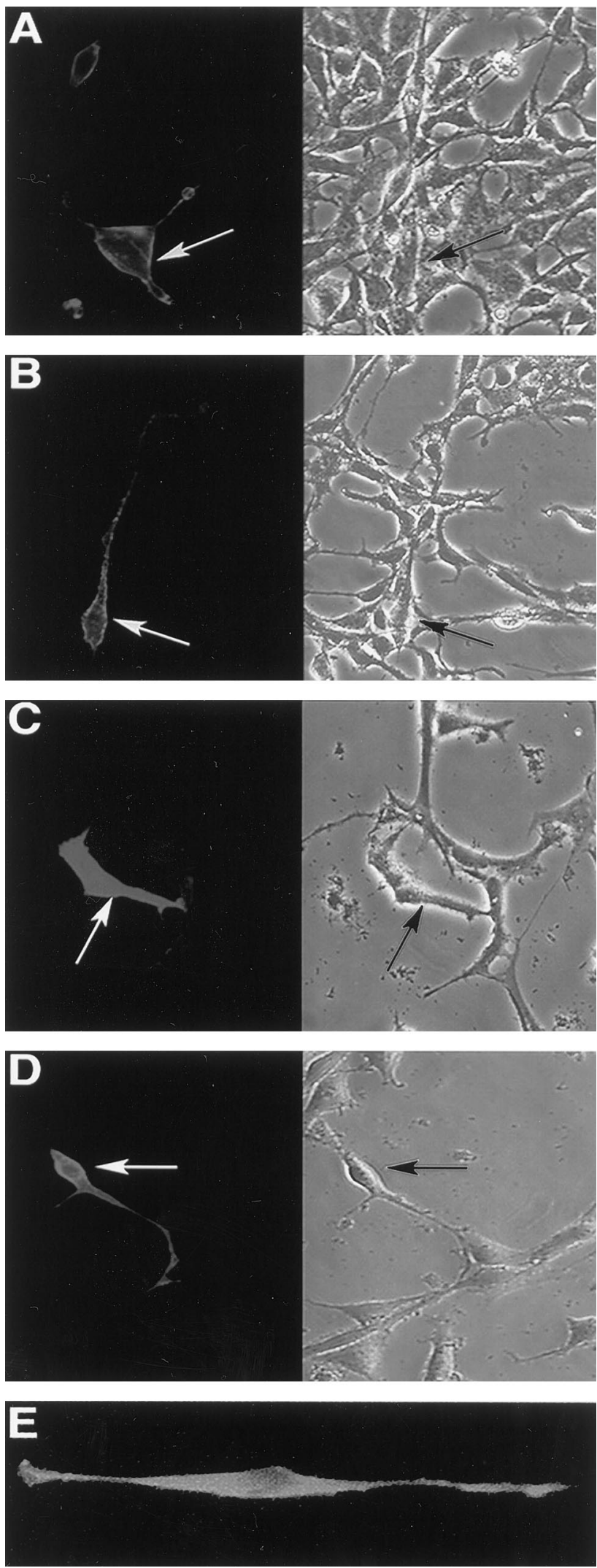

Figure 2. Epitope-tagged receptors are expressed at the cell surface. Nonpermeabilized HEK293 cells were fixed in $4 \%$ paraformaldehyde and immunostained with 9E10 $(A, B), 5 \mathrm{~B} 6(C, D)$, or M2 $(E)$ to detect transiently transfected epitope-tagged $\operatorname{TrkB}(A)$, epitope-tagged TrkC $(B)$, epitope-tagged TrkB-T1 $(C)$, and epitope-tagged TrkB-T2 $(D)$. NIH 3 T3 fibroblasts expressing FLAG-TrkB-T1 $(E)$ are shown. Bright-field

\section{RESULTS}

\section{Epitope-tagged receptors are processed, appropriately expressed at the cell surface, and responsive to neurotrophin}

Epitope-tagged forms of rat TrkB and TrkC receptors were produced for several reasons: (1) to allow reliable detection of Trk receptors using well characterized epitope tag antibodies, (2) to identify transfected receptors in neurons expressing high levels of endogenous Trk receptors, and (3) to determine unambiguously the subcellular destinations of the various alternatively spliced TrkB receptor isoforms. For both TrkB and TrkC, a c-myc epitope was inserted near the $\mathrm{N}$ terminal of the fully processed receptor (Fig. 1A). The epitope at this site should be accessible to antibody but unlikely to interfere with ligand binding, which has been associated with the extracellular leucine-rich motifs (Windisch et al., 1995) and the immunoglobulin-like domains (Haniu et al., 1995; Perez et al., 1995; Urfer et al., 1995). To confirm that the epitope-tagged forms of TrkB and TrkC were expressed appropriately, wild-type and myc-tagged receptors were expressed in HEK293 cells, immunoprecipitated with the pan-Trk antibody 203, and then immunoblotted either with anti-Trk 203 or with 9E10, a monoclonal antibody directed against the myc epitope tag. Figure $1, B$ and $C$, shows that wild-type and myctagged TrkB and TrkC were readily immunoprecipitated from transfected cells with the 203 antibody and were detected on immunoblots using either 203 or 9E10, confirming that the myc epitope-tagged receptors were appropriately expressed. Transiently transfected cells typically produced a fully processed $140-$ $155 \mathrm{kDa}$ isoform and an immature $120 \mathrm{kDa}$ form. With the epitope-tagged forms of the receptors, there was a marked increase in the ratio of the immature to mature isoforms, indicating that the myc-tagged receptors may be less efficiently processed than their wild-type counterparts in HEK293 cells.

To confirm that the epitope-tagged receptors were present at the cell surface, HEK293 or N2A neuroblastoma cells were transiently transfected with expression constructs, fixed without permeabilization, and then immunostained with either 9E10 (full-length TrkB and TrkC), 5B6 (TrkB-T1 and -T2), or M2 antibody (TrkB-T1). Figure 2 shows that transiently transfected cells demonstrated typical cell surface immunoreactivity when stained with the appropriate epitope-directed antibody and that nontransfected cells within the same field showed very low levels of background staining. Immunostaining revealed that each of the tagged receptor isoforms was distributed over the entire cell surface, extending to the ends of filopodia, with no evidence of sequestration in any plasmalemmal subdomain.

The epitope tag was located far from the putative ligandbinding sites of the Trk receptors, but perturbation of receptor structure could potentially disrupt ligand-induced signaling and, as a result, disrupt appropriate vectorial sorting. To confirm that the tagged isoforms of full-length TrkB and TrkC bound and responded to neurotrophin, we used $\mathrm{PC} 12$ cells to determine whether epitope-tagged TrkB and TrkC mediate neurotrophin responses. PC12 cells normally survive and extend neurites only in response to NGF, but PC12 cells transfected with wild-type

\section{$\leftarrow$}

images of the fields are shown on the right in $A-D$. Arrows indicate the same transfected cell in adjacent panels. Control experiments (data not shown) confirmed that $4 \%$ paraformaldehyde alone does not permeabilize HEK293 cells; intracellular epitopes are detected after fixation with $4 \%$ paraformaldehyde only if cells were treated with $0.3 \%$ Triton X-100. 

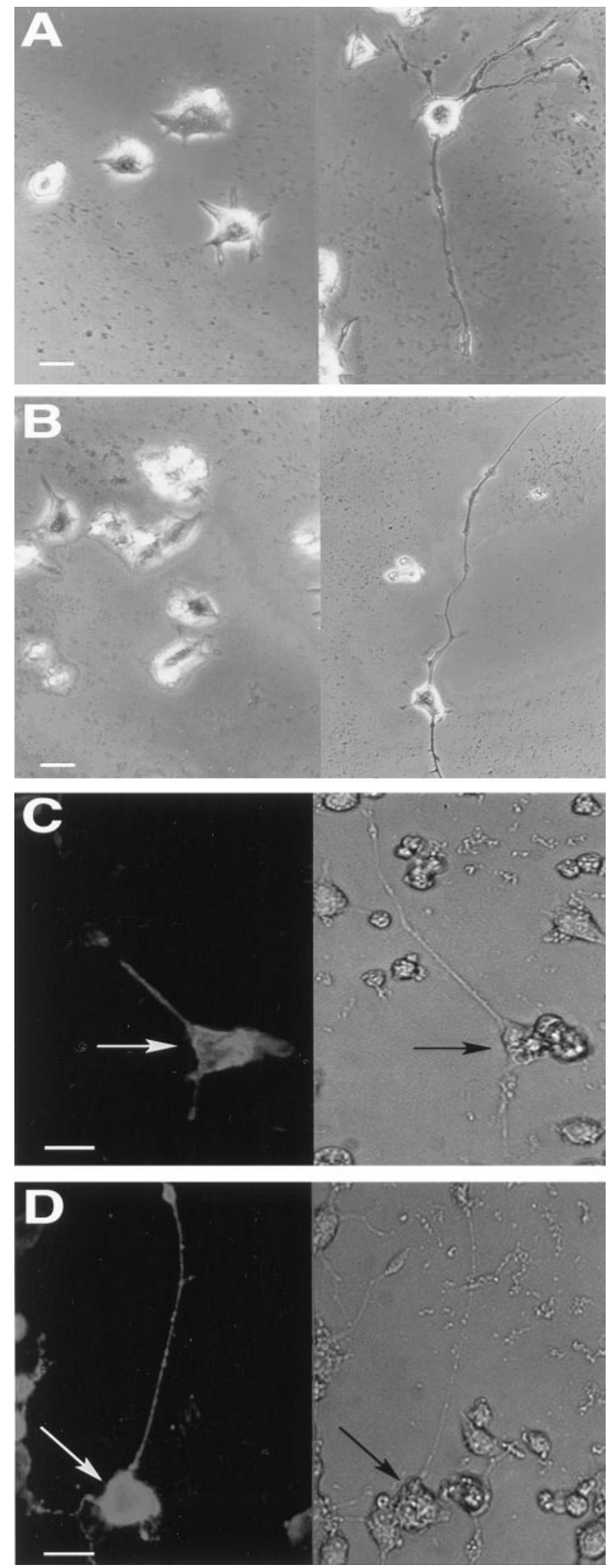

Figure 3. Epitope-tagged TrkB and TrkC are functional and distributed throughout cell bodies and neurites of differentiated PC12 cells. $A, B$, PC12 cells were transiently transfected with either tagged $\operatorname{TrkB}(A)$ or $\operatorname{TrkC}(B)$, treated with $100 \mathrm{ng} / \mathrm{ml} \mathrm{BDNF}(A$; right) or NT-3 (B; right) for $3 \mathrm{~d}$, and then examined for neurite outgrowth. Left, Cells without neu rotrophin are shown. $C, D, \mathrm{PC} 12$ cells were transfected with either myc-TrkB $(C)$ or myc-TrkC $(D)$, treated with BDNF $(C)$ or NT-3 $(D)$ for $3 \mathrm{~d}$, and then fixed and immunostained using 9E10. Scale bars, $20 \mu \mathrm{m}$.
TrkB or TrkC show robust responses to BDNF and NT-3, respectively (Ip et al., 1993). Figure 3, $A$ and $B$, shows that PC12 cells transiently transfected with myc-TrkB show BDNF-mediated neurite extension and that PC12 cells transiently transfected with myc-TrkC showed similar robust responses to NT-3. Cell surface immunostaining of the transfected PC12 cells showed that both myc-TrkB and myc-TrkC were distributed uniformly throughout the cells (Fig. 3C,D), with no apparent concentration in any cellular plasmalemmal domain. Some of the cells transfected with myc-TrkB and myc-TrkC showed BDNF- or NT-3-mediated neurite outgrowth in the absence of detectable Trk receptor surface staining. Nontransfected PC12 cells never showed BDNF- or NT-3-dependent neurite outgrowth, indicating that low levels of myc-Trk receptors that are expressed below our immunocytochemical detection limit are capable of mediating biological responses to neurotrophins. Together, these results indicate that the myc-tagged full-length Trk receptors are efficiently activated by their cognate neurotrophins.

\section{Full-length TrkB and TrkC and truncated TrkB isoforms are not strongly sorted in MDCK cells}

In epithelial cell lines, cell surface proteins can be selectively directed to basolateral or apical domains. Sorting of several non-neuronal receptor tyrosine kinases, including the hepatocyte growth factor receptor, the epidermal growth factor receptor, and the insulin-like growth factor-I receptor, has been examined in epithelial cells, and all of these are selectively retained in the basolateral domain (Maratos-Flier et al., 1987; Crepaldi et al., 1994; Remacle-Bonnet et al., 1995). Studies comparing targeting in MDCK cells and neurons have revealed that membrane proteins sorted to the basolateral domain of MDCK cells are retained in the somatodendritic domain of neurons and that proteins retained within the apical domain of MDCK cells tend to traffic to the axonal compartment of neurons (Dotti and Simons, 1990; Jareb and Banker, 1998). Examples include the $\mathrm{GABA}_{\mathrm{A}}$ receptor, which is dendritic in neurons and targeted basolaterally in MDCK cells (Killisch et al., 1991; Perez-Velazquez and Angelides, 1993), and GABA transporter proteins GAT-1 and GAT-3, which are limited to the axons in neurons and to the apical membranes of MDCK cells (Pietrini et al., 1994; Ahn et al., 1996).

Using the MDCK model system, we asked whether TrkB and TrkC are preferentially sorted to apical or basolateral domains. MDCK cells grown to confluence on porous filter culture supports were transiently transfected with myc-TrkB or myc-TrkC and then immunostained for the epitope-tagged Trk receptor and for ZO-1, a zonula adherens junctional protein that defines the boundary between apical and basolateral domains (Stevenson et al., 1986). Optical sectioning by confocal microscopy revealed that myc-TrkB was not present in the apical domain of transfected MDCK cells but that cell surface staining was readily detected in the basolateral membrane, below the level of ZO-1 (Fig. 4A). Transfected cells showed considerable intracellular staining, presumably reflecting myc-TrkB within the endoplasmic reticulum and/or Golgi apparatus. MDCK cells transfected with myc-TrkC showed a similar distribution, but low levels of apical immunostaining were detected (Fig. $4 B$ ). We attempted to produce stable Trk-transfected MDCK cell sublines to study this distribution biochemically, but this cell type did not tolerate TrkB or TrkC expression; cell surface expression of myc-TrkB or myc-TrkC was not detected in any of $\sim 200$ G418-resistant clones examined.

Immunocytochemical localization of the HVG-tagged trun- 

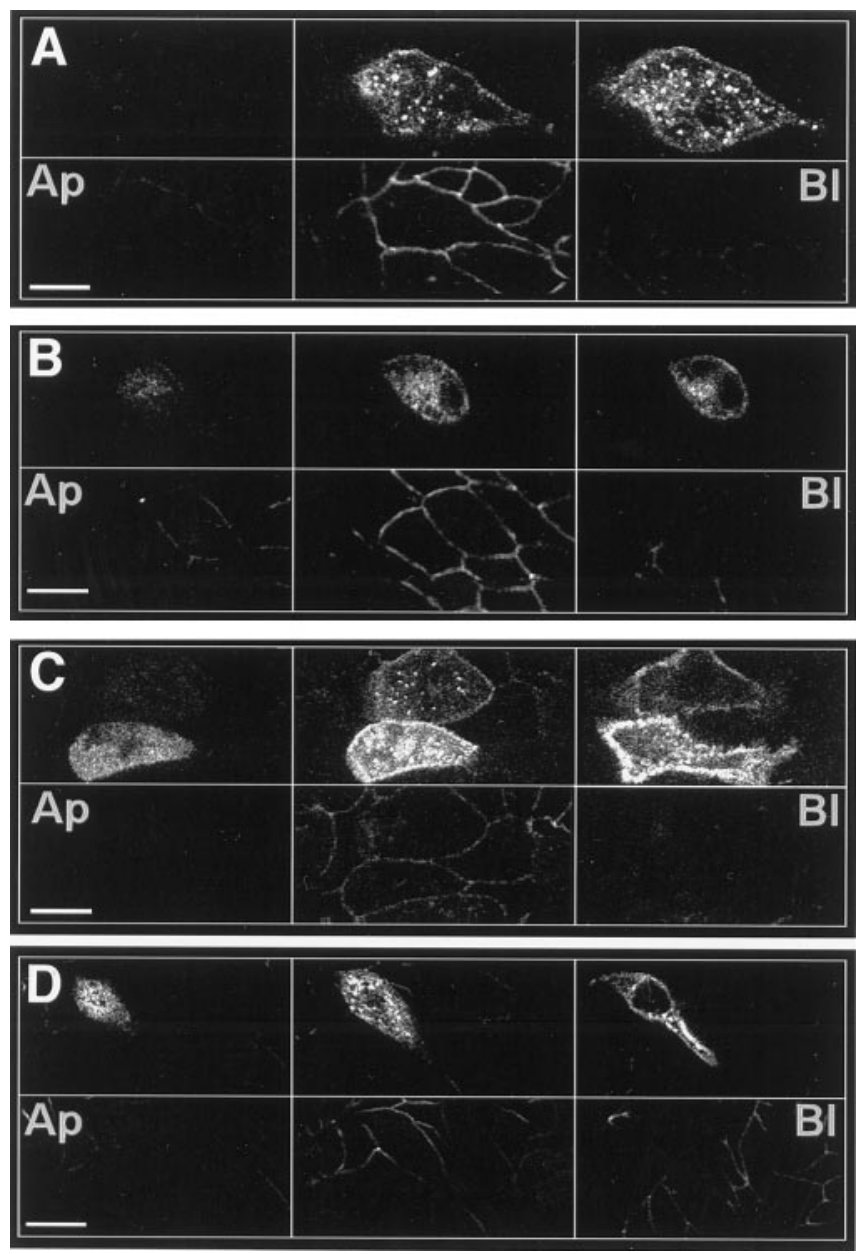

Figure 4. Myc-TrkC, HVG-TrkB-T1, and HVG-TrkB-T2 are not preferentially distributed in MDCK cells, but full-length myc-TrkB is excluded from the apical domain. MDCK cells transiently transfected with full-length TrkB $(A)$, TrkC $(B)$, TrkB-T1 $(C)$, or TrkB-T2 $(D)$ were immunostained with 9E10 ( $A, B$; top panels) or with 5B6 (C, D; top panels) and with anti-ZO-1 ( $A-D$; bottom panels $)$ to define tight junctions. Each set of panels shows confocal optical sections that progress from apical ( $A p$; right) to basolateral $(B l ; l e f t)$. Scale bars, $20 \mu \mathrm{m}$.

cated TrkB isoforms within MDCK cells did not reveal any preferential distribution. Figure 4, $C$ and $D$, shows that expression of the TrkB-T1 and -T2 isoforms was readily detected above, at, and below the level of ZO-1 staining in MDCK cells, indicating little or no preferential sorting to or retention within basolateral or apical domains. As with the full-length forms of TrkB and TrkC, considerable amounts of the truncated TrkB receptors were detected intracellularly, presumably reflecting relatively slow transit of these receptor isoforms through the endoplasmic reticulum and Golgi.

\section{Distribution of Trk receptor isoforms in cultured hippocampal neurons}

To study trafficking of Trk receptor in neurons, we transiently transfected epitope-tagged Trk receptor isoforms into pyramidal neurons cultured from E18 rat hippocampi. Dissociated neurons were allowed to polarize and express distinct axonal and somatodendritic domains for $5 \mathrm{~d}$, transfected, and then fixed for immunocytochemical analysis $1-4 \mathrm{~d}$ later. Figure $5 A$ shows a typical pyramidal hippocampal neuron immunostained with an antibody directed against MAP2, which is located within dendritic pro-
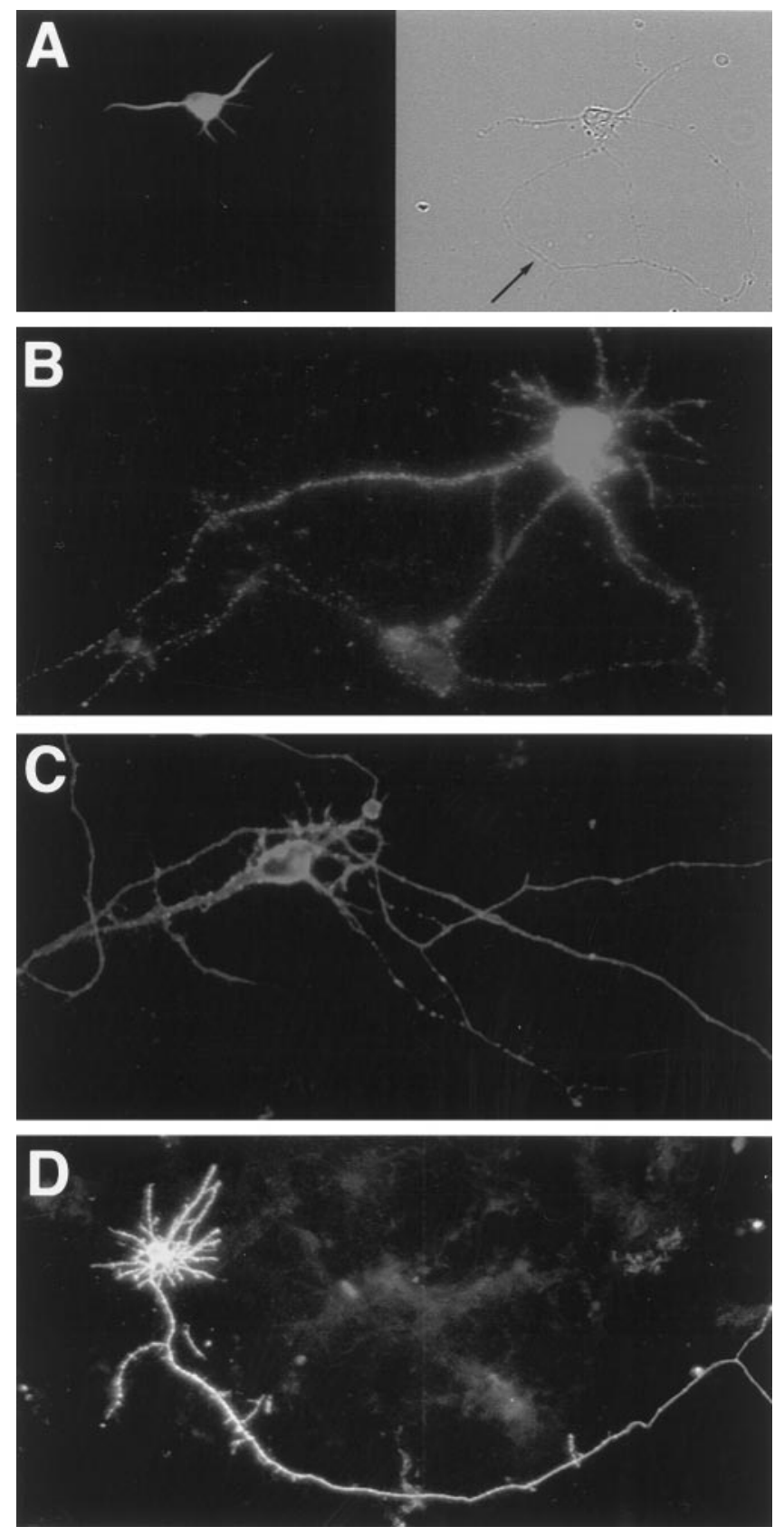

Figure 5. Neither full-length nor truncated receptors are preferentially sorted in dissociated hippocampal neurons. $A$, MAP2 immunostaining of a typical pyramidal cell demonstrates polarization in our culture system. The arrow (right) indicates the axonal process in the phase panel. $B-D$, Hippocampal neurons transiently transfected with myc-TrkB $(B)$, mycTrkC $(C)$, or FLAG-TrkB-T1 $(D)$ were fixed in paraformaldehyde and immunostained with 9E10 or M2. Scale bars, $20 \mu \mathrm{m}$.

cesses of polarized neurons (Caceres et al., 1984). The prominent MAP2 staining within the dendritic processes and the absence of immunoreactivity from the axonal domain indicate that these cells are indeed well polarized. The retention of full-length TrkB in the basolateral domain of MDCK cells suggested that TrkB may be selectively enriched in the somatodendritic domain. However, pyramidal neurons transfected with full-length TrkB or TrkC showed no evidence of receptor sorting to either axonal or somatodendritic domains. Instead, full-length TrkB and TrkC 

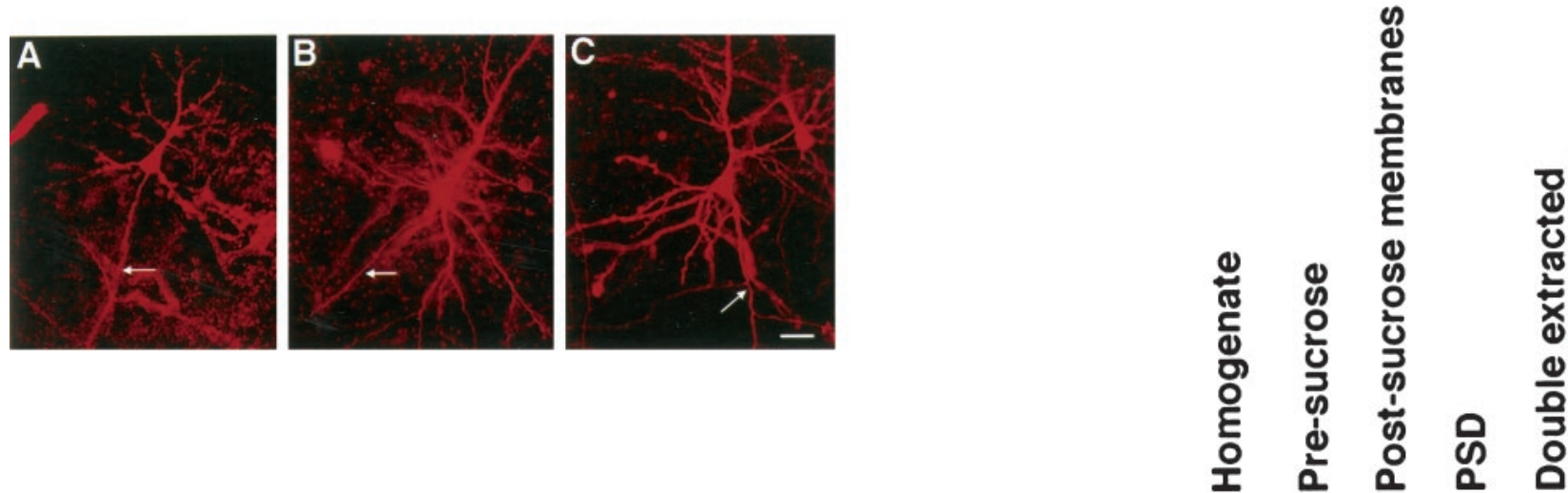

CaMK II
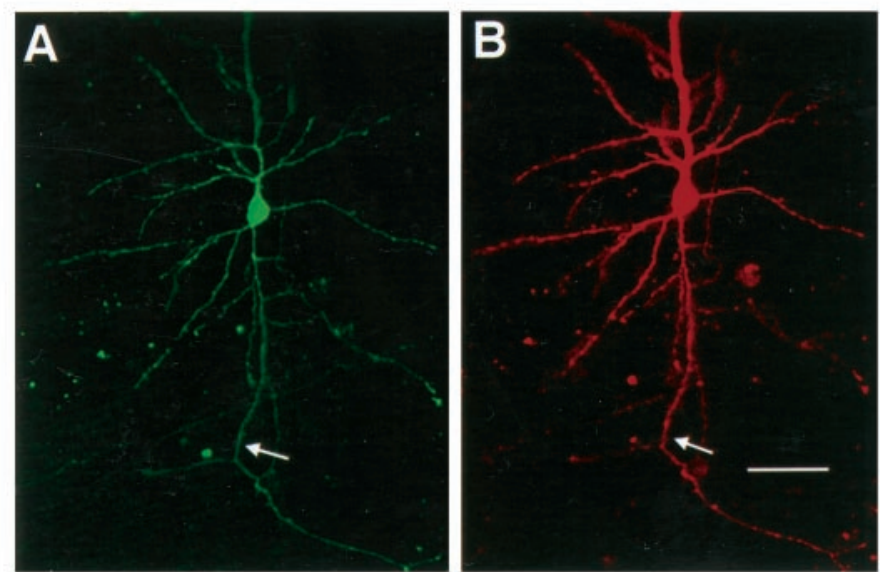

\section{Synaptotagmin}

\author{
GluRI
}

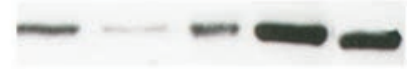

GIuRIVRIII

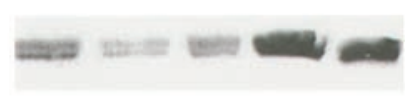

TrkB.out

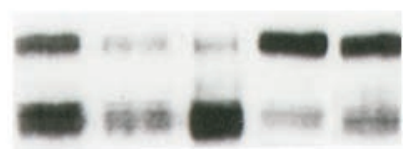

Figure 6. Left, top. Full-length TrkB and TrkC and truncated TrkB-T1 show no preferential sorting in pyramidal neurons in visual cortical brain slices. Ferret cortical slices were transfected with myc-TrkB $(A)$, myc-TrkC $(B)$, or FLAG-tagged TrkB-T1 $(C)$ and immunostained with either 9E10 $(A, B)$ or M2 (C). Arrows indicate axonal processes. Scale bar, $20 \mu \mathrm{m}$.

Figure 7. Left, bottom. Truncated TrkB is not excluded from any cell surface neuronal compartment. To determine whether truncated TrkB isoforms can be detected throughout transfected neurons, we cotransfected cortical slices with FLAG-TrkB-T1 and BFP. Double immunofluorescent staining was performed using M2 $(A)$ or anti-BFP $(B)$. Arrows indicate axons. Scale bar, $20 \mu \mathrm{m}$.

Figure 8. Right. Full-length and truncated receptors are present in postsynaptic densities. Brain homogenate, the presucrose gradient fraction, and postsynaptic density fractions were prepared as described in Materials and Methods, and equal amounts of each fraction were separated by SDS-PAGE and immunoblotted with antibodies directed against the CaM kinase-II (CaMK II), synaptotagmin, GluRI, or GluRII/RIII or with TrkB.out, which recognizes both full-length and truncated forms of TrkB.

appeared evenly distributed in all areas of these polarized cells (Fig. 5B,C).

For neuronal transfections of truncated TrkB isoforms, we focused on TrkB-T1 rather than TrkB-T2 because TrkB-T1 is the predominant truncated isoform expressed in the CNS (Allendoerfer et al., 1994; Escandón et al., 1994; Knüsel et al., 1994; Valenzuela et al., 1993; Fryer et al., 1996). Hippocampal neurons transfected with a FLAG-tagged form of TrkB-T1 showed uniformly strong expression in all parts of neurons, and as with full-length TrkB or TrkC, it did not show any preferential localization in axons or dendrites (Fig. 5D).

\section{Distribution of Trk receptor isoforms in cortical brain slices}

Although dissociated hippocampal neurons are partially polarized in culture, neurons maintained in vitro do not contain the full complement of sorting signals that are present in vivo. For exam- ple, the microtubule-associated protein Tau has a strictly axonal distribution in vivo but is distributed throughout polarized primary pyramidal neurons maintained in vitro (Dotti et al., 1987). To examine the Trk receptor in situ, we investigated the distribution of Trk receptors in short-term cortical slice cultures. Neurons within slice preparations maintain their organotypic organization and more closely approximate the in vivo situation than do primary dissociated cultures yet still allow ready access for transfection and microscopy (Stoppini et al., 1991). To assess Trk receptor distribution, we used particle-mediated gene transfer to transfect epitope-tagged Trk receptors into pyramidal neurons in brain slices prepared from 2-week-old ferret visual cortex. In agreement with the results obtained from dissociated hippocampal neurons, myc-TrkB and myc-TrkC were distributed evenly throughout pyramidal neurons, with no selective sorting to axonal or dendritic processes (Fig. 6A,B). FLAG-TrkB-T1 showed a distribution similar to that of its full-length counterpart, with no 
overt enrichment in axonal or dendritic compartments (Fig. 6C). To verify that tagged receptors were expressed throughout transfected neurons, we transfected Trk receptor expression plasmids with BFP, a variant of GFP that fills dendrites and axons of transfected neurons (see Lo et al., 1994). Cotransfected neurons immunostained for BFP and for FLAG-TrkB-T1 revealed complete overlap between BFP and the T1 isoform (Fig. 7). Similar results were obtained for full-length TrkB and TrkC (data not shown), indicating that both TrkB and TrkC are trafficked to all regions of transfected neurons.

\section{TrkB receptor isoforms in postsynaptic densities}

The results described above indicate little preferential sorting of Trk receptors into the major cellular compartments of polarized epithelial cells and postmitotic neurons. To confirm this biochemically, we used subcellular fractionation to determine whether TrkB receptors might be differentially sorted to, or excluded from, synapses of central neurons in vivo. PSDs were isolated from adult rat brain and were examined by immunoblotting to determine whether full-length or truncated TrkB isoforms are selectively enriched or depleted. Fractions were assayed by immunoblot using an antibody directed against synaptotagmin, which is normally excluded from PSDs, or with antibodies directed against CaM kinase-II, GluRI, or GluRII/III, all of which are selectively enriched in PSDs (Matthew et al., 1981; Kelly et al., 1984; Rubio and Wenthold, 1997). Figure 8 shows that each of these marker proteins shows the expected distribution, with CaM kinase-II, GluRI, or GluRII/III strongly enriched in PSDs and synaptotagmin depleted from the PSD fraction. Immunoblots for full-length TrkB revealed that the receptor was clearly present in the PSD fraction but only moderately enriched compared with CaM kinase-II, GluRI, or GluRII/III. Truncated TrkB is present within the PSD fractions at detectable levels, yet its level is depleted in the PSD compared with the total brain homogenate. This latter finding is consistent with the known cellular distribution of truncated TrkB; much of the truncated TrkB expression within the adult CNS is within glial cells (Frisén et al., 1993; Rudge et al., 1994; Armanini et al., 1995; Wetmore and Olson, 1995) and does not have access to the PSD compartment. These results suggest that truncated TrkB expressed in neurons is neither selectively retained nor excluded from biochemically isolated PSDs but that the full-length receptor may be moderately enriched in this compartment.

\section{DISCUSSION}

The critical role of neurotrophins and Trk receptors in promoting the survival and development of the peripheral nervous system is well established, but the function of neurotrophins in the CNS has been more difficult to ascertain. Considerable evidence now indicates that neurotrophins in the CNS regulate neuronal form and function both during development and into adulthood (for review, see Thoenen, 1995; Lewin and Barde, 1996; McAllister et al., 1999). The mechanisms underlying neurotrophin regulation of plasticity remain poorly understood but likely include both long-range and localized effects on neuronal function and structure. Local interactions between ligand and receptor may be regulated by mechanisms including activity-dependent neurotrophin targeting or release (Blochl and Thoenen, 1995, 1996; Keith et al., 1996; Thoenen, 1995; Canossa et al., 1997; Rutherford et al., 1997; Tongiorgi et al., 1997), dependence on concurrent electrical activity (McAllister et al., 1996), and specific spatial organization of Trk receptor expression and function. For this latter possibility, we hypothesized that the existence of multiple alternatively spliced variants of each Trk receptor might provide a powerful mechanism for local modulation of neurotrophin responsiveness via differential targeting of specific catalytic and kinase-deficient Trk isoforms and have asked whether neurons sort distinct TrkB receptor isoforms to particular subcellular domains. We found that the full-length TrkB receptor is not vectorially sorted in neurons. TrkB was excluded from the apical domain of MDCK cells yet was present in axonal and somatodendritic compartments in dissociated hippocampal neurons and in pyramidal neurons in cortical brain slices, with no apparent enrichment in either compartment. Similarly, the truncated isoforms of TrkB were not preferentially sorted in MDCK cells, in cultured hippocampal neurons, or in neurons within cortical slices. Finally, we found that full-length and truncated TrkB receptors are present but not strongly enriched in postsynaptic densities isolated from intact adult rat brain.

Our studies provide the first direct analysis of the distribution of TrkB receptor isoforms in polarized cells. Recent immunostaining studies have demonstrated that TrkB receptors are detectable in the cell soma, axons, and dendrites of several different classes of CNS neurons, but these experiments could not resolve whether different TrkB isoforms were differentially distributed within neurons because the antibodies used either did not distinguish between TrkB isoforms or recognized only the full-length receptor (Cabelli et al., 1996; Fryer et al., 1996; Yan et al., 1997). In this study, we created epitope-tagged receptors to determine unambiguously the subcellular localization of each of the Trk isoforms studied. Moreover, using particle-mediated gene transfer, we were able to visualize the location of Trk receptor isoforms in individual dendrites and axons in neurons within slice preparations. Such precise localization has not been possible using conventional immunostaining studies because of the high density of neuronal processes in most regions of the CNS.

Our findings are important for two main reasons. First, we found that Trk receptors are distributed throughout axons and dendrites. According to traditional views of neurotrophic interactions, receptors for target-derived factors should be present within axonal domains so that a neuron can respond to a trophic agent released by its target (Purves et al., 1988). Our studies demonstrate that Trk receptors are indeed expressed in axons but that they are also expressed in somatodendritic compartments, suggesting that neurotrophins may function as autocrine, paracrine, or anterograde factors within the CNS (Acheson et al., 1995; Levine et al., 1995; von Bartheld et al., 1995; Acheson and Lindsay, 1996; Patterson et al., 1996; Canossa et al., 1997; Rutherford et al., 1997).

Second, our localization studies suggest that localized neurotrophin effects do not result from differential sorting of full-length and truncated receptors to subdomains of the neuronal plasma membrane. We were particularly interested in the subcellular targeting of the truncated TrkB receptors because they have been shown to have dominant-inhibitory and autonomous signaling properties (Eide et al., 1996; Ninkina et al., 1996; Baxter et al., 1997). However, truncated TrkB isoforms did not show restricted localization in MDCK cells, dissociated hippocampal neurons, or cortical neurons in intact brain slices, suggesting that differential sorting of these isoforms is not a mechanism that restricts neurotrophin effects to particular neuronal subdomains. In fact, the correlated expression patterns of the truncated receptors with their full-length isoform support models in which truncated receptors regulate full-length TrkB activity generally by ligand 
sequestration or dominant-negative repression. These studies do not address whether the truncated TrkB receptors have an autonomous signaling role but indicate that any such function is unlikely to be compartmentalized by receptor localization.

In our final series of experiments, we used a biochemical approach to determine whether the TrkB receptor is enriched in synapses, because recent studies on the effects of BDNF and NT-3 have suggested that neurotrophin signaling may be targeted to synaptic sites (Kang and Schuman, 1995; Thoenen, 1995; Akaneya et al., 1996; Levine et al., 1996; Stoop and Poo, 1996; Carmignoto et al., 1997; Vicario-Abejón et al., 1998). Postsynaptic densities isolated from adult rat brain were examined for enrichment or depletion of TrkB receptor isoforms, and TrkB was found to be moderately enriched in PSD fractions when compared with proteins such as glutamate receptors and CaM kinaseII, which are known to be concentrated within these structures (Kelly et al., 1984; Rubio and Wenthold, 1997). Low levels of truncated TrkB were present within PSDs but at levels considerably lower than that in total brain homogenate, suggesting that PSDs have a relatively high ratio of full-length to truncated TrkB. Because of our immunocytochemical results, this distribution is unlikely to reflect differential sorting or retention of these isoforms but rather that glia are the major source of truncated TrkB expression in the adult CNS (Frisén et al., 1993). Wu et al. (1996) recently showed that full-length TrkB is present within PSDs and suggested that the receptor may be concentrated at this location. Although our analysis clearly shows that full-length TrkB is present within PSDs, our comparison of the relative enrichment of the full-length TrkB receptor in PSDs to other marker proteins indicates that the full-length TrkB enrichment in this location is moderate and supports our immunocytochemical data that show that TrkB is present throughout the neuron.

One surprising finding in our studies was the lack of correlation between full-length TrkB targeting in MDCK cells and neurons. It has generally been assumed, on the basis of studies by Dotti and Simons (1990) that compared the targeting of viral proteins in MDCK cells and neurons, that neurons and epithelial cells use common targeting mechanisms. Many subsequent studies with several mammalian proteins, such as the $\mathrm{GABA}_{\mathrm{A}}$ receptor and GABA transporter proteins, have shown a strong correspondence between sorting to the basolateral domain of MDCK cells and to the somatodendritic domain of neurons and between the apical domain of MDCK cells and the axonal compartment (Dotti and Simons, 1990; Dotti et al., 1991; Killisch et al., 1991; PerezVelazquez and Angelides, 1993; Pietrini et al., 1994; de Hoop et al., 1995; Ahn et al., 1996). However, we found that full-length TrkB was limited to the basolateral region of MDCK cells but was expressed in both axons and dendrites of neurons. We are not the first to discover the lack of correlation in the targeting of membrane proteins between polarized epithelial cells and neurons. For example, $\beta$-amyloid precursor protein and $\mathrm{Na}^{+}-\mathrm{K}^{+}$ATPase, both basolaterally targeted in MDCK cells, are not directed to dendrites in neurons (Hammerton et al., 1991; Pietrini et al., 1992; Haass et al., 1995; Yamazaki et al., 1995). Certain apically targeted proteins in MDCK cells, including the p75 neurotrophin receptor, are also not spatially restricted in neurons but are expressed in both axons and dendrites (Jareb and Banker, 1998).

Our studies do not fully exclude the possibility that overexpression of the Trk receptor isoforms or the addition of the epitope tags to these receptors may disrupt targeting of these proteins. However, we believe that this is unlikely for several reasons. First, previous immunocytological studies using antibodies against the extracellular domain of the TrkB receptor isoforms to examine endogenous TrkB receptor localization revealed staining throughout neurons and in cell bodies, axons, and dendrites (Cabelli et al., 1995; Fryer et al., 1996; Yan et al., 1997). These studies, however, could not determine whether individual isoforms exhibited restriction to specific subcellular areas. Second, many studies have shown that overexpression of polarized proteins does not alter their polarized expression either in MDCK cells or in neurons (Dotti and Simons, 1990; Ahn et al., 1996; Jareb and Banker, 1998). Third, the presence of epitope tags does not alter the targeting of neuronal proteins, such as opioid receptors, glutamate receptors, and various actin isotypes (Keith et al., 1996; Petersen et al., 1997; Bassel et al., 1998; Lissin et al., 1998). Fourth, Trk receptor constructs with three different epitope tags with distinct amino acid sequences produced comparable results. Finally, epitope tags did not alter neurotrophin-dependent signaling of TrkB and TrkC, measured by their ability to support survival and neurite outgrowth in PC12 cells, increasing the likelihood that these tags did not alter trafficking of the Trk receptors in our experiments.

In conclusion, our results show that Trk receptors are not strongly sorted to particular neuronal subdomains and suggest that local effects of the neurotrophins on central neurons are not regulated by spatially restricted receptor distributions. Each of the receptor isoforms examined showed a relatively homogeneous distribution in both axonal and dendritic compartments with good agreement between dissociated neuronal cultures and neurons in intact brain slices. The TrkB distribution within biochemically defined PSDs agrees with our immunocytochemical analysis, showing only moderate enrichment of full-length TrkB isoforms in these structures. Thus, if local interactions between neurotrophins and their receptors do occur, they must do so via other mechanisms such as activity-dependent neurotrophin release and dependence on concurrent electrical activity.

\section{REFERENCES}

Acheson A, Lindsay RM (1996) Non target-derived roles of the neurotrophins. Philos Trans R Soc Lond [Biol] 351:417-422.

Acheson A, Conover JC, Fandl JP, DeChiara TM, Russell M, Thadani A, Squinto SP, Yancopoulos GD, Lindsay RM (1995) A BDNF autocrine loop in adult sensory neurons prevents cell death. Nature 374:450-453.

Ahn J, Mundigl O, Muth TR, Rudnick G, Caplan MJ (1996) Polarized expression of GABA transporters in Madin-Darby canine kidney cells and cultured hippocampal neurons. J Biol Chem 271:6917-6924.

Akaneya Y, Tsumoto T, Hatanaka H (1996) Brain-derived neurotrophic factor blocks long-term depression in rat visual cortex. J Neurophysiol 76:4198-4201.

Allendoerfer KL, Cabelli RJ, Escandón E, Kaplan DR, Nikolics K, Shatz CJ (1994) Regulation of neurotrophin receptors during the maturation of the mammalian visual system. J Neurosci 14:1795-1811.

Armanini M, McMahon S, Sutherland J, Shelton D, Phillips H (1995) Truncated and catalytic isoforms of trkB are co-expressed in neurons of rat and mouse CNS. Eur J Neurosci 7:1403-1409.

Ausebel FM, Brent R, Kingston RE, Moore DD, Seidman JG, Smith JA, Struhl K (1989) Current protocols in molecular biology, Chap 9. New York: Greene.

Bartlett W, Banker G (1984) An electron microscopic study of the development of axons and dendrites by hippocampal neurons in culture. J Neurosci 4:1944-1953.

Bassel GJ, Zhang H, Byrd AL, Femino AM, Taneja KL, Lifshitz LM, Herman IM, Kosik KS (1998) Sorting of beta-actin mRNA and protein to neurites and growth cones in culture. J Neurosci 18:251-265.

Baxter G, Radeke M, Kuo R, Makrides V, Hinkle B, Hoang R, MedinaSelby A, Coit D, Valenzuela P, Feinstein S (1997) Signal transduction mediated by the truncated trkB receptor isoforms, trkB.T1 and trkB.T2. J Neurosci 17:2683-2690.

Biffo S, Offenhauser N, Carter BD, Barde YA (1995) Selective binding 
and internalisation by truncated receptors restrict the availability of BDNF. Development 121:2461-2470.

Blochl A, Thoenen H (1995) Characterization of nerve growth factor (NGF) release from hippocampal neurons: evidence for a constitutive and an unconventional sodium-dependent regulated pathway. Eur J Neurosci 7:1220-1228.

Blochl A, Thoenen H (1996) Localization of cellular storage compartments and sites of constitutive and activity-dependent release of nerve growth factor (NGF) in primary cultures of hippocampal neurons. Mol Cell Neurosci 7:173-190.

Cabelli RJ, Hohn A, Shatz CJ (1995) Inhibition of ocular dominance column formation by infusion of NT-4/5 or BDNF. Science 267:1662-1665.

Cabelli RJ, Allendoerfer KL, Radeke MJ, Welcher AA, Feinstein SC, Shatz CJ (1996) Changing patterns of expression and subcellular localization of trkB in the developing visual system. J Neurosci 16:7965-7980.

Caceres A, Banker G, Steward O, Binder L, Payne M (1984) MAP2 is localized to the dendrites of hippocampal neurons which develop in culture. Dev Brain Res 13:314-318.

Campenot RB (1987) Local control of neurite sprouting in cultured sympathetic neurons by nerve growth factor. Brain Res 465:293-301.

Canossa M, Griesbeck O, Berninger B, Campana G, Kolbeck R, Thoenen H (1997) Neurotrophin release by neurotrophins: implications for activity-dependent neuronal plasticity. Proc Natl Acad Sci USA 94:13279-13286.

Carlin RK, Grab DJ, Cohen RS, Siekevitz P (1980) Isolation and characterization of postsynaptic densities from various brain regions: enrichment of different types of post-synaptic densities. J Cell Biol 86:831-843.

Carmignoto G, Pizzorusso T, Tia S, Vicini S (1997) Brain-derived neurotrophic factor and nerve growth factor potentiate excitatory synaptic transmission in the rat visual cortex. J Physiol (Lond) 498:153-164.

Crepaldi T, Pollack AL, Prat M, Zborek A, Mostov K, Comoglio PM (1994) Targeting of the SF $\leq \mathrm{GF}$ receptor to the basolateral domain of polarized epithelial cells. J Cell Biol 125:313-320.

Davies AM (1994) The role of neurotrophins in the developing nervous system. J Neurobiol 25:1334-1348.

Davis S, Aldrich TH, Valenzuela DM, Wong V, Furth ME, Squinto SP, Yancopoulos GD (1991) The receptor for ciliary neurotrophic factor. Science 253:59-63.

de Hoop M, von Poser C, Lange C, Ikonen E, Hunziker W, Dotti CG (1995) Intracellular routing of wild-type and mutated polymeric immunoglobulin receptor in hippocampal neurons in culture. J Cell Biol 130:1447-1459.

Dotti C, Simons K (1990) Polarized sorting of viral glycoproteins to the axons and dendrites of hippocampal neurons in culture. Cell 62:63-72.

Dotti C, Banker G, Binder L (1987) The expression and distribution of microtubule-associated proteins tau and MAP2 in hippocampal neurons in the rat in situ and in cell culture. Neuroscience 23:121-130.

Dotti C, Parton R, Simons K (1991) Polarized sorting of glypiated proteins in hippocampal neurons. Nature 349:158-161.

Eide FE, Vining ER, Eide BL, Zang K, Wang X, Reichardt LF (1996) Naturally occurring truncated receptors have dominant inhibitory effects on brain-derived neurotrophic factor signaling. J Neurosci 16:3123-3129.

Escandón E, Soppet D, Rosenthal A, Mendoza-Ramírez J, Szönyi É, Burton LE, Henderson CE, Parada LF, Nikolics K (1994) Regulation of neurotrophin receptor expression during embryonic and postnatal development. J Neurosci 14:2054-2068.

Frisén J, Verge VK, Fried K, Risling M, Persson H, Trotter J, Hökfelt T, Lindholm D, Ray J (1993) Characterization of glial trkB receptors: differential response to injury in the central and peripheral nervous systems. Proc Natl Acad Sci USA 90:4971-4975.

Fryer RH, Kaplan DR, Feinstein SC, Radeke MJ, Grayson DR, Kromer LF (1996) Developmental and mature expression of full-length and truncated trkB receptors in the rat forebrain. J Comp Neurol 374:21-40.

Fryer RH, Kaplan DR, Kromer LF (1997) Truncated trkB receptors on nonneuronal cells inhibit BDNF-induced neurite outgrowth in vitro. Exp Neurol 148:616-627.

Greene LA, Tischler AS (1976) Establishment of a noradrenergic clonal line of rat adrenal pheochromocytoma cells which respond to nerve growth factor. Proc Natl Acad Sci USA 73:2424-2428.

Haapasalo A, Saarlainen T, Moshnyakov M, Arumäe U, Kiema T,
Saarma M, Wong G, Castrén E (1999) Expression of naturally occurring truncated TrkB neurotrophin receptor induces outgrowth of filopodia and processes in neuroblastoma cells. Oncogene 18:1285-1296.

Haass C, Koo EH, Capell A, Teplow DB, Selkoe DJ (1995) Polarized sorting of beta-amyloid precursor protein and its proteolytic products in MDCK cells is regulated by two independent signals. J Cell Biol 128:537-547.

Hammerton RW, Krzeminski KA, Mays RW, Ryan TA, Wollner DA, Nelson WJ (1991) Mechanism for regulating cell surface distribution of $\mathrm{Na}+, \mathrm{K}+$-ATPase in polarized epithelial cells. Science 251:847.

Haniu M, Talvenheimo J, Le J, Katta V, Welcher A, Rohde MF (1995) Extracellular domain of neurotrophin receptor trkB: disulfide structure, $N$-glycosylation sites, and ligand binding. Arch Biochem Biophys 322:256-264.

Ip NY, Stitt TN, Tapley P, Klein R, Glass DJ, Fandl J, Greene LA, Barbacid M (1993) Similarities and differences in the way neurotrophins interact with the Trk receptors in neuronal and nonneuronal cells. Neuron 10:137-149.

Jareb M, Banker G (1998) The polarized sorting of membrane proteins expressed in cultured hippocampal neurons using viral vectors. Neuron 20:855-867.

Kang H, Schuman EM (1995) Long-lasting neurotrophin-induced enhancement of synaptic transmission in the adult hippocampus. Science 267:1658-1662.

Kaplan DR, Miller FD (1997) Signal transduction by the neurotrophin receptors. Curr Opin Cell Biol 9:213-221.

Keith DE, Murray SR, Zaki PA, Chu PC, Lissin DV, Kang L, Evans CJ, von Zastrow M (1996) Morphine activates opioid receptors without causing their rapid internalization. J Biol Chem 271:19021-19024.

Kelly PT, McGuinness TL, Greengard P (1984) Evidence that the major postsynaptic density protein is a component of a $\mathrm{Ca} 2+/$ calmodulindependent protein kinase. Proc Natl Acad Sci USA 81:945-949.

Killisch I, Dotti CG, Laurie DJ, Luddens H, Seeburg PH (1991) Expression patterns of GABAa receptor subtypes in developing hippocampal neurons. Neuron 7:927-936.

Knüsel B, Rabin SJ, Hefti F, Kaplan DR (1994) Regulated neurotrophin receptor responsiveness during neuronal migration and early differentiation. J Neurosci 14:1542-1554.

Levine ES, Dreyfus CF, Black IB, Plummer MR (1995) Brain-derived neurotrophic factor rapidly enhances synaptic transmission in hippocampal neurons via postsynaptic tyrosine kinase receptors. Proc Natl Acad Sci USA 92:8074-8077.

Levine ES, Dreyfus CF, Black IB, Plummer MR (1996) Selective role for trkB neurotrophin receptors in rapid modulation of hippocampal synaptic transmission. Mol Brain Res 38:300-303.

Lewin GR, Barde YA (1996) Physiology of the neurotrophins. Annu Rev Neurosci 19:289-317.

Li Y, Xu Y, Ju D, Lester HA, Davidson N, Schuman EM (1998) Expression of a dominant negative trkB receptor, T1, reveals a requirement for presynaptic signaling in BDNF-induced synaptic potentiation in cultured hippocampal neurons. Proc Natl Acad Sci USA 95:10884-10889.

Lissin DV, Gomperts SN, Carroll RC, Christine CW, Kalman D, Kitamura M, Hardy S, Nicoll RA, Malenka RC, von Zastrow M (1998) Activity differentially regulates the surface expression of synaptic AMPA and NMDA glutamate receptors. Proc Natl Acad Sci USA 95:7097-7102.

Lo DC, McAllister AK, Katz LC (1994) Neuronal transfection in brain slices using particle-mediated gene transfer. Neuron 13:1263-1268.

Maratos-Flier A, Kao C, Verdin EM, King GL (1987) Receptormediated vectorial transcytosis of epidermal growth factor by MadinDarby canine kidney cells. J Cell Biol 105:1595-1601.

Matthew WD, Tsavaler L, Reichardt LF (1981) Identification of a synaptic vesicle-specific membrane protein with a wide distribution in neuronal and neurosecretory tissue. J Cell Biol 91:257-269.

McAllister AK, Lo DC, Katz LC (1995) Neurotrophins regulate dendritic growth in developing visual cortex. Neuron 15:791-803.

McAllister AK, Katz LC, Lo DC (1996) Neurotrophin regulation of cortical dendritic growth requires activity. Neuron 17:1057-1064.

McAllister AK, Katz LC, Lo DC (1997) Opposing roles for endogenous BDNF and NT-3 in regulating cortical dendritic growth. Neuron 18:767-778.

McAllister AK, Katz LC, Lo DC (1999) Neurotrophins and synaptic plasticity. Annu Rev Neurosci 22:295-318. 
Mizushima S, Nagata S (1990) pEF-BOS, a powerful mammalian expression vector. Nucleic Acids Res 18:5322-5326.

Naismith JH, Sprang SR (1998) Modularity in the TNF-receptor family. Trend Biochem Sci 23:74-79.

Ninkina N, Adu J, Fischer A, Pinon LGP, Buchman VL, Davies AM (1996) Expression and function of trkB variants in developing sensory neurons. EMBO J 15:6385-6393.

Patterson SL, Abel T, Deuel TAS, Martin KC, Rose JC, Kandel ER (1996) Recombinant BDNF rescues deficits in basal synaptic transmission and hippocampal LTP in BDNF knockout mice. Neuron 16:1137-1145.

Perez P, Coll PM, Hempstead BL, Martin-Zanca D, Chao MV (1995) NGF binding to the trk tyrosine kinase receptor requires the extracellular immunoglobulin-like domains. Mol Cell Neurosci 6:97-105.

Perez-Velazquez JL, Angelides KJ (1993) Assembly of GABAa receptor subunits determines sorting and localization in polarized cells. Nature 361:457-460.

Petersen SA, Fetter RD, Noordermeer JN, Goodman CS, DiAntonio A (1997) Genetic analysis of glutamate receptors in Drosophila reveals a retrograde signal regulating presynaptic transmitter release. Neuron 19:1237-1248.

Pietrini G, Matteoli M, Banker G, Caplan MJ (1992) Isoforms of the $\mathrm{Na}, \mathrm{K}$-ATPase are present in both axons and dendrites of hippocampal neurons in culture. Proc Natl Acad Sci USA 89:8414-8418.

Pietrini G, Suh YJ, Edelmann L, Rudnick G, Caplan MJ (1994) The axonal gamma-aminobutyric acid transporter GAT-1 is sorted to the apical membranes of polarized epithelial cells. J Biol Chem 269:4668-4674.

Purves D, Snider WD, Voyvodic JT (1988) Trophic regulation of nerve cell morphology and innervation in the autonomic nervous system. Nature 336:123-128.

Remacle-Bonnet M, Garrouste F, El Atiq F, Marvaldi J, Pommier G (1995) Cell polarity of insulin-like growth factor binding protein-6 in differentiated human colon cancer cells. J Clin Invest 96:192-200.

Rubio ME, Wenthold RJ (1997) Glutamate receptors are selectively targeted to postsynaptic sites in neurons. Neuron 18:939-950.

Rudge JS, Li Y, Pasnikowski EM, Mattsson K, Pan L, Yancopoulos GD, Wiegand SJ, Lindsay RM, Ip NY (1994) Neurotrophic factor receptors and their signal transduction capabilities in rat astrocytes. Eur J Neurosci 6:693-705.

Rutherford LC, DeWan A, Lauer HM, Turrigiano GG (1997) Brainderived neurotrophic factor mediates the activity-dependent regulation of inhibition in neocortical cultures. J Neurosci 17:4527-4535.

Snider WD (1994) Functions of the neurotrophins during nervous system development: what the knockouts are teaching us. Cell 77:627-638.

Stevenson BR, Siliciano JD, Mooseker MS, Goodenough DA (1986)
Identification of ZO-1: a high molecular weight polypeptide associated with the tight junction (zonula occludens) in a variety of epithelia. J Cell Biol 103:755-766.

Stoop R, Poo MM (1996) Synaptic modulation by neurotrophic factors. Prog Brain Res 109:359-364.

Stoppini L, Buchs PA, Muller D (1991) A simple method for organotypic cultures of nervous tissue. J Neurosci Methods 37:173-182.

Thoenen H (1995) Neurotrophins and neuronal plasticity. Science 270:593-598.

Tongiorgi E, Righi M, Cattaneo A (1997) Activity-dependent dendritic targeting of BDNF and trkB mRNAs in hippocampal neurons. J Neurosci 17:9492-9505.

Urfer R, Tsoulfas P, O'Connell L, Shelton DL, Parada LF, Presta LG (1995) An immunoglobulin-like domain determines the specificity of neurotrophin receptors. EMBO J 14:2795-2805.

Valenzuela DM, Maisonpierre PC, Glass DJ, Rojas E, Nunez L, Kong Y, Gies DR, Stitt TN, Ip NY, Yancopoulos GD (1993) Alternative forms of rat TrkC with different functional capabilities. Neuron 10:963-974.

Vicario-Abejón C, Collin C, McKay RDG, Segal M (1998) Neurotrophins induce formation of functional excitatory and inhibitory synapses between cultured hippocampal neurons. J Neurosci 18:7256-7271.

von Bartheld CS, Schober A, Kinoshita Y, Williams R, Ebendal T, Bothwell M (1995) Noradrenergic neurons in the locus coeruleus of birds express TrkA, transport NGF, and respond to NGF. J Neurosci 15:2225-2239.

Wetmore C, Olson L (1995) Neuronal and nonneuronal expression of neurotrophins and their receptors in sensory and sympathetic ganglia suggest new intracellular trophic interactions. J Comp Neurol 353:143-159.

Windisch JM, Markensteiner R, Lang ME, Auer B, Schneider R (1995) Brain-derived neurotrophic factor, neurotrophin-3, and neurotrophin-4 bind to a single leucine-rich motif of trkB. Biochemistry 34:11256-11263.

Wu K, Xu J, Suen P, Levine E, Huang Y, Mount HTJ, Lin S, Black IB (1996) Functional trkB neurotrophin receptors are intrinsic components of the adult brain postsynaptic density. Mol Brain Res 43:286-290.

Xia Z, Dudek H, Miranti CK, Greenberg ME (1996) Calcium influx via the NMDA receptor induces early gene transcription by a MAP kinase/ ERK-dependent mechanism. J Neurosci 16:5425-5436.

Yamazaki T, Selkoe DJ, Koo EH (1995) Trafficking of cell surface beta-amyloid precursor protein: retrograde and transcytotic transport in cultured neurons. J Cell Biol 129:431-442.

Yan Q, Radeke MJ, Matheson CR, Talvenheimo J, Welcher AA, Feinstein SC (1997) Immunocytochemical localization of trkB in the central nervous system of the adult rat. J Comp Neurol 378:135-157. 